\title{
Jevons' Paradox Revisited: \\ Do Russian Environmental Institutions Contribute to Green Growth?
}

\author{
Irina P. Glazyrina* and Irina A. Zabelina \\ Department for ecological economics \\ Institute of Natural Resources, Ecology and Cryology SB RAS \\ Chita, Russian Federation \\ Transbaikal State University \\ Chita, Russian Federation
}

Received 12.11.2019, received in revised form 11.03.2020, accepted 10.04.2020

\begin{abstract}
The purpose of this work is to quantify the effectiveness of the environmental institutions in Russia from the perspective of the concepts of green economy and green growth. For these purposes we used the indicators of the environmental and economic dynamics, which can be considered as characteristics of the quality of growth from an environmental point of view: eco-intensity, representing direct quantitative characteristics of resource use or negative impact per unit of economic result, and decoupling coefficients. The authors adhere to the approach to the quantitative assessment of green growth, proposed by P. Victor in 2014. The proposed tools allow analyzing environmental and economic trends for individual regions, industries and types of negative anthropogenic impact. Based on the calculation results, it can be concluded that Russian environmental institutions are not a sufficiently fine instrument of regulation, as they do not fully take into account the regional characteristics and, in general, do not create sufficient incentives for greening the economy. The results of the work can be used both in theoretical studies of ecological and economic dynamics for individual countries and regions, and in practical development of programs for the development of territories.
\end{abstract}

Keywords: eco-intensity, decoupling, environmental and economic trends.

The work was carried out within the framework of the basic research program of the Siberian Branch of Russian Academy of Sciences (XI.174.1).

Research area: economics and national economy.

Citation: Glazyrina, I.P., Zabelina, I.A. (2020). Jevons' paradox: do Russian environmental institutions contribute to green growth? J. Sib. Fed. Univ. Humanit. Soc. Sci., 13(4), 496-506. DOI: 10.17516/1997$1370-0584$.

\footnotetext{
(C) Siberian Federal University. All rights reserved

* Corresponding author E-mail address: iglazyrina@bk.ru ORCID: 0000-0001-6774-9284 (Glazyrina); 0000-0003-4464-2593 (Zabelina)
} 
Introduction:

\section{theoretical framework and statement of the problem}

Most studies investigating the resource economy in the last three decades are inextricably linked with the issues of environmental protection, both in theoretical research and in practical developments. Due to the fact that the consequences of negative anthropogenic impact (despite its initially local nature) are becoming increasingly important for large areas, the issue of environmental modernization arises not only for individual industries, but also for socio-ecological and economic systems, which state environmental institutions are called upon to solve.

Tools for "systemic" modernization are almost always developed and introduced through the efforts of states. They can be varied to a greater or lesser extent. In the European Union, the set of these tools is quite broad: not only environmental taxes and fees, but also rules for the use of natural resources (including land use, subsoil use, water use, forest use, etc.), as well as support of the development and implementation of new environmentally friendly technologies (Baker, 2000). The same measures are also used in Russia for the greening of production facilities. However, both in the West and in Russia, they do not always produce the desired results, and this largely depends on the quality of state environmental institutions and the existing institutional environment.

Environmental measures of state regulation are almost always aimed at stimulating environmental modernization of production facilities, while the target is more efficient use of natural resources. This means getting better economic results with using less natural resources and causing less damage to the environment in each specific case of production of goods and services. But does "individual technological modernization" always mean ecological modernization of socio-ecological and economic systems as a whole?

This is called into question by the effect noted in some studies (Alcott, 2005; Hovardas, 2016; etc.), similar to that described in the famous "Jevons paradox" during the in- dustrial revolution. Jevons (Jevons, 1905) noted that although the initial motivation for modernizing steam engines was to reduce the consumption of coal, it nevertheless resulted in the increase of coal consumption. More efficient use of coal in steam engines actually increased the overall consumption of coal, iron, and other resources. This, in turn, led to significant negative environmental consequences, which are well known. Similar processes often occur when environmental management measures create comparative advantages for those industries that use resources more efficiently and reduce their negative impact on the environment. Theoretically, as a result of economic incentives for technology development, the efficiency of using natural resources increases and the per unit demand of economic output decreases. However, in practice an improvement in efficiency increases the commercial appeal of the modernized sector (Warner, 2010; Wolfe, 2012) with the investment being directed there and ultimately increasing the demand for natural resources and the negative anthropogenic impact on natural systems.

The term "green growth" in most works refers to the path of development that leads to the achievement of the goals of the green economy and assumes an increase in the gross domestic product. However, this definition certainly requires the application of quantitative "diagnostic" tools, the use of which could give an answer to the question: is the observed growth really "green"? The conceptual scheme was proposed in P. Victor's work (Victor, 2015). He used one of the well-known indicators of eco-intensity: the amount of carbon emissions per unit of gross domestic product (GDP), and on this basis developed a rule that allows to characterize the dynamics of development as "green", "brown" or "black" growth in relation to the climatic effects caused by the economic activity, which can also be applied to the characteristics of the economic degrowth. This work was presented in a report at the Kenneth Boulding's award ceremony in 2014 in Reykjavik. His calculations showed that the economic growth in Canada over the past decades can be characterized mainly as "brown". 
Victor's model was used in the work of (Shang et al., 2015) to assess the dynamics of the Chinese economy, also in relation to carbon emissions. The authors showed that for the period from 1971 to 2010, the economic growth in China was "black" or "brown". Some improvements have been observed since 2005 .

The purpose of this work is to quantify the effectiveness of the environmental institutions in Russia from the perspective of the concepts of "green" economy and "green" growth.

The methodology assumes the use of characteristics of environmental and economic dynamics for these purposes, which can be considered as growth quality indicators from an environmental point of view (Glazyrina, Faleychik, et al., 2005). The most common indicators are eco-intensity, which provide direct quantitative characteristics of resource use or negative impact per unit of economic output. (De Haan, 2004; Glazyrina et al., 2018; Zabelina, Deluga, 2019a). These include widely used indicators of GDP energy intensity (Bobylev et al., 2010; Gulbrandsen et al., 2010). In the past few years, researchers have been attracted to an approach based on the assessment of decoupling - the divergence or mismatch of economic growth rates, resource consumption and negative environmental impact (Decoupling..., 2011; Nagvi, Zwickl, 2017; OECD..., 2002; Shkiperova, 2014; Zabelina, 2019; Kudryavtseva, Yakovleva, 2019). This method is becoming popular not only in scientific research, but also in public environmental discourses related to climate change.

\section{Methods}

The authors adhere to the approach to quantifying "green growth" proposed by $\mathrm{P}$. Victor in (Victor, 2015). In accordance with this approach, the positive value of the coefficient of decoupling observed during the studied time interval is a necessary but insufficient condition for the green growth. The authors proposed a methodology for diagnosing "green" growth, the idea of which also goes back to P. Victor, and is described in detail in (Glazyrina, Zabelina, 2016; Glazyrina, Zabelina, 2018).

To measure the effect of decoupling, the following formula is used:

$$
D_{t}=1-\frac{E_{t} / Y_{t}}{E_{0} / Y_{0}},
$$

where $E_{0}$ and $E_{t}$ are the indicators that characterize the negative impact on the environment in the initial and current periods; $Y_{0}$ and $Y_{t}$ are the indicators that characterize an economic result. The positive value of the indicator demonstrates that the trends in economic and environmental dynamics have opposite directions. If the value of the coefficient of $D_{t}$ equals to zero or is negative, then there is no decoupling effect. The positive value of the decoupling coefficient is a necessary but insufficient condition for the green growth. This may correspond to the "brown" growth, that is, a situation where the efficiency of resource use increases, and at the same time the total volume of their use increases as well. That is, we are talking about an effect similar to the "Jevons paradox". This is associated with a certain pessimism in assessing the prospects for economic growth per se and discussing the concept of the inevitability of degrowth in the scientific literature (O'Connor, 1994; Victor, 2015). However, the emergence and further sustainable manifestation of the decoupling effect indicates that a step has been taken towards a positive dynamic in the development of ecological and economic systems.

The gross regional product was used as an economic indicator in this work. The indicators are presented in 2009 prices and adjusted to take into account the cost of a fixed set of goods and services, which may differ significantly in different regions. The approach proposed in (Mel'nikov, 2005) was used for the correction, which was also used for this class of problems in (Zabelina, Deluga, 2019b).

\section{Results and discussion}

The most common tool of state regulation to encourage the greening of production processes is the introduction of payments for negative environmental impact. However, this tool does not always yield unambiguously positive results. In a number of countries, environmental taxes become a "drop in the ocean" and have little impact on the environ- 
mental processes. In other cases, we can say that this is the drop that "sharpens the stone". Russia is a large country with a high degree of diversity of natural and socio-economic conditions. However, the main instruments of environmental regulation and corresponding institutions for all regions are formed at the Federal level. We believe that quantitative indicators of environmental and economic dynamics can serve as characteristics of the effectiveness of these institutions for different conditions and territories. They can also identify industries and sectors that are the main sources of disadvantage, and identify activities where institutions "work" with a high or low degree of efficiency. As an example, we report the calculations results of the coefficients of decoupling for the energy sector. In Table 1 data is presented for the Russian Far East regions for two categories: when the economic result is selected as (A) the contribution to GRP, and (B) the physical volume of energy produced. We can see that the trends do not always coincide. In the Irkutsk region within the 2009-2016 period, the decoupling coefficient is positive, while calculations of natural indicators give a negative value. This means that the contribution of GRP (and, accordingly, the decoupling coefficient) has increased more due to the growth of cost components, rather than physical energy production. A similar situation is observed in some other regions. Obviously, in this case, it is more appropriate to use calculations in natural quantities.

The spatial distribution of the decoupling coefficient values for total air emissions and GRP for the entire country is shown in Fig. 1. Despite the fact that air emissions from stationary sources are one of the most "controlled" processes of the negative impact on the environment, we see that the dynamics of environmental and economic processes in this context is very heterogeneous. Institutions for paid environmental impacts, including standards for payments for emissions of pollutants, are established at the federal level. As a result, $28 \%$ of regions for the 2009-2017 period have a negative decoupling coefficient for this type of impact. This shows that the format of environmental institutions in this case does not take into account the heterogeneity of the natural and socio-economic conditions of a large country. This is due to large spatial differences in their effectiveness.

Table 1. The decoupling coefficient (Dt) for the economic activity

"Electricity, gas and water production and supply": air emissions from stationary sources

\begin{tabular}{|c|c|c|c|c|c|c|}
\hline \multirow[t]{2}{*}{ Region } & \multicolumn{3}{|c|}{$\begin{array}{l}\text { (A) Contribution of the en- } \\
\text { ergy industry to the GRP }\end{array}$} & \multicolumn{3}{|c|}{$\begin{array}{l}\text { (B) Volume of production of } \\
\text { electric and thermal energy }\end{array}$} \\
\hline & $2009-2012$ & $2012-2016$ & $2009-2016$ & $2009-2012$ & $2012-2016$ & $2009-2016$ \\
\hline Amur Region & -0.31 & 0.17 & -0.09 & -0.20 & -0.001 & -0.20 \\
\hline Jewish Autonomous Region & 0.09 & 0.29 & 0.35 & 0.05 & 0.15 & 0.19 \\
\hline Trans-Baikal Territory & -0.03 & 0.37 & 0.35 & 0.08 & 0.19 & 0.25 \\
\hline Irkutsk Region & -0.11 & 0.26 & 0.18 & -0.29 & 0.09 & -0.18 \\
\hline Kamchatka Territory & 0.33 & -0.03 & 0.32 & & 0.03 & \\
\hline Magadan Region & 0.08 & -0.12 & -0.04 & 0.04 & 0.02 & 0.06 \\
\hline Primorye Territory & 0.11 & 0.13 & 0.23 & 0.21 & 0.27 & 0.42 \\
\hline Republic of Buryatia & 0.12 & 0.21 & 0.30 & 0.05 & 0.20 & 0.24 \\
\hline Republic of Sakha (Yakutia) & 0.20 & 0.27 & 0.42 & 0.12 & 0.15 & 0.25 \\
\hline Sakhalin Region & 0.14 & 0.44 & 0.52 & 0.33 & 0.43 & 0.62 \\
\hline Khabarovsk Territory & 0.09 & 0.09 & 0.17 & 0.12 & 0.07 & 0.18 \\
\hline Chukotka Autonomous Area & 0.04 & 0.28 & 0.31 & 0.10 & -0.29 & -0.16 \\
\hline Russian Federation as a whole & 0.06 & 0.14 & 0.19 & 0.02 & 0.14 & 0.15 \\
\hline
\end{tabular}

Source: calculated by the authors using the official data from the Federal State Statistics Service. 


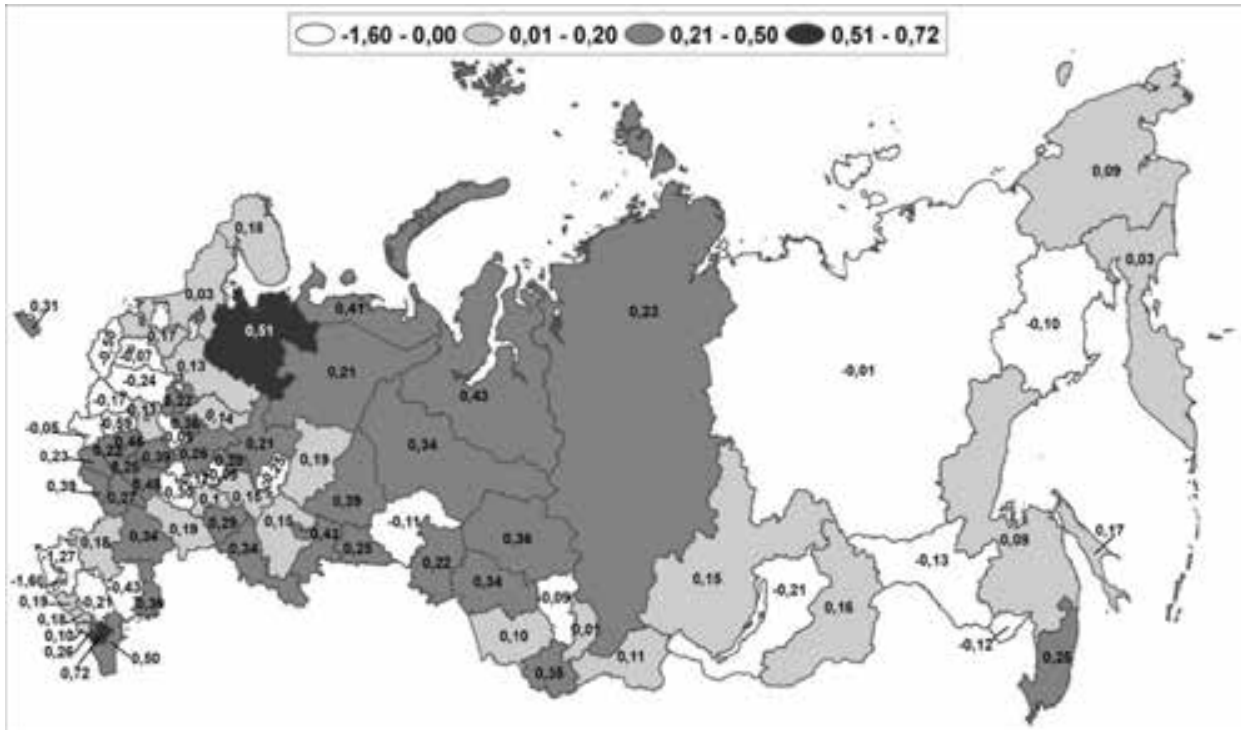

Fig. 1. The decoupling coefficient $\left(D_{t}\right)$ in Russia's regions: air emissions from stationary sources, 2009 and 2017

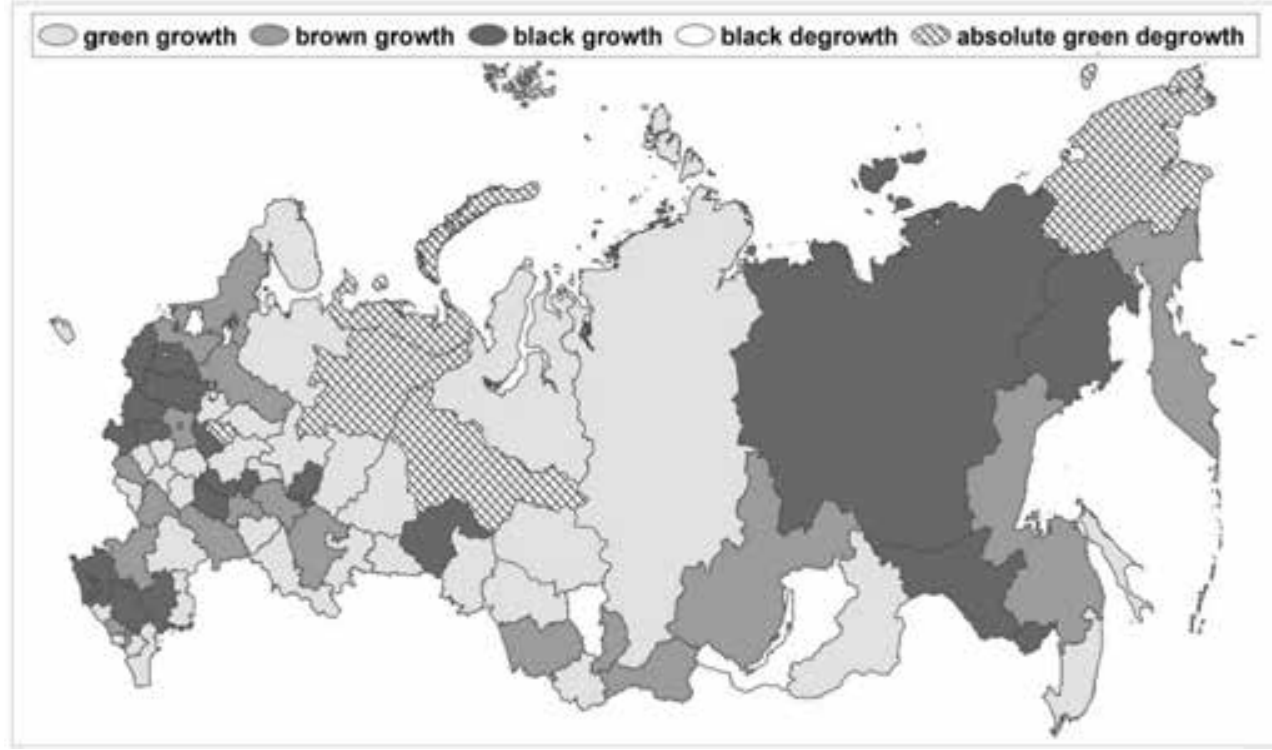

Fig. 2. Spatial distribution of the "color" of growth in the Russian regions during the 2009-2017 period by the ratio of the total emissions from stationary sources and GRP

As already noted, a positive value of the coefficient of decoupling does not guarantee the availability of "green" growth. Just like the decoupling effect, the "color" of growth is determined for a specific territory and for a fixed period of time (Glazyrina, Zabelina, 2018). Fig- ure 2 shows that, brown growth is diagnosed for the 2009-2017 period in 20 regions with positive decoupling. This means that despite the decrease in eco-intensity, the total number of emissions has increased. The number of regions with brown and black growth (in relation 
to the total emissions into the atmosphere) is $49 \%$ - and there are such territories in the East and West of the country. It is worth paying attention to the fact that in some regions, where oil and gas resources are traditionally extracted (and a significant part of revenues to the Federal budget of the Khanty-Mansiysk and Nenets Autonomous Areas is formed), the changes for 2009-2017 are characterized as absolute green degrowth. This means that both the total air emissions and the emissions per unit of GRP are reduced. This effect is due to the fact that the GRP values are adjusted to take into account the level of consumer prices, which in these regions is (talking about "the level") consistently higher compared to other territories.

The proposed tools can be used both for individual sectors and for specific types of impact. Figure 3 shows the spatial distribution of the decoupling effect in relation to the $\mathrm{SO}_{2}$ emissions. According to the Russian regulations, this substance belongs to the class III hazard and has a negative impact on the human cardiovascular system (Tian, 2014). Therefore, there are an increased payment for its emissions. However, in $10(13 \%)$ regions the negative value of the coefficient of decoupling has been identified. This means that the total $\mathrm{SO}_{2}$ emissions have increased in these regions, despite the government regulation.

Figure 4 shows that the number of environmentally disadvantaged areas is even greater in terms of trends towards a green economy: in $7(9 \%)$ of the regions we see black growth, in $10(13 \%)$ - brown growth, and in $3(4 \%)$ - black degrowth.

Calculations show that the coefficient of decoupling can be positive for some polluting substances and negative for others. This is also true for the "color" of economic growth. This is illustrated by the example in Table 2 . In the Krasnoyarsk Territory, there was a green growth in solid particle emissions between 2009 and 2017, but there was a brown increase in nitrogen oxide emissions and a black increase in carbon monoxide emissions. At the same time, in the Trans-Baikal Territory, there is a green growth in all three types of impact. These differences are related to the different structure of the economy, industry, and energy supply. That is, in each case, problems are "formed" at the regional and local levels. At the same time, the main powers of regulation, including the establishment of standards for emissions to be concentrated at the federal level. This impedes not only the "diagnosis",

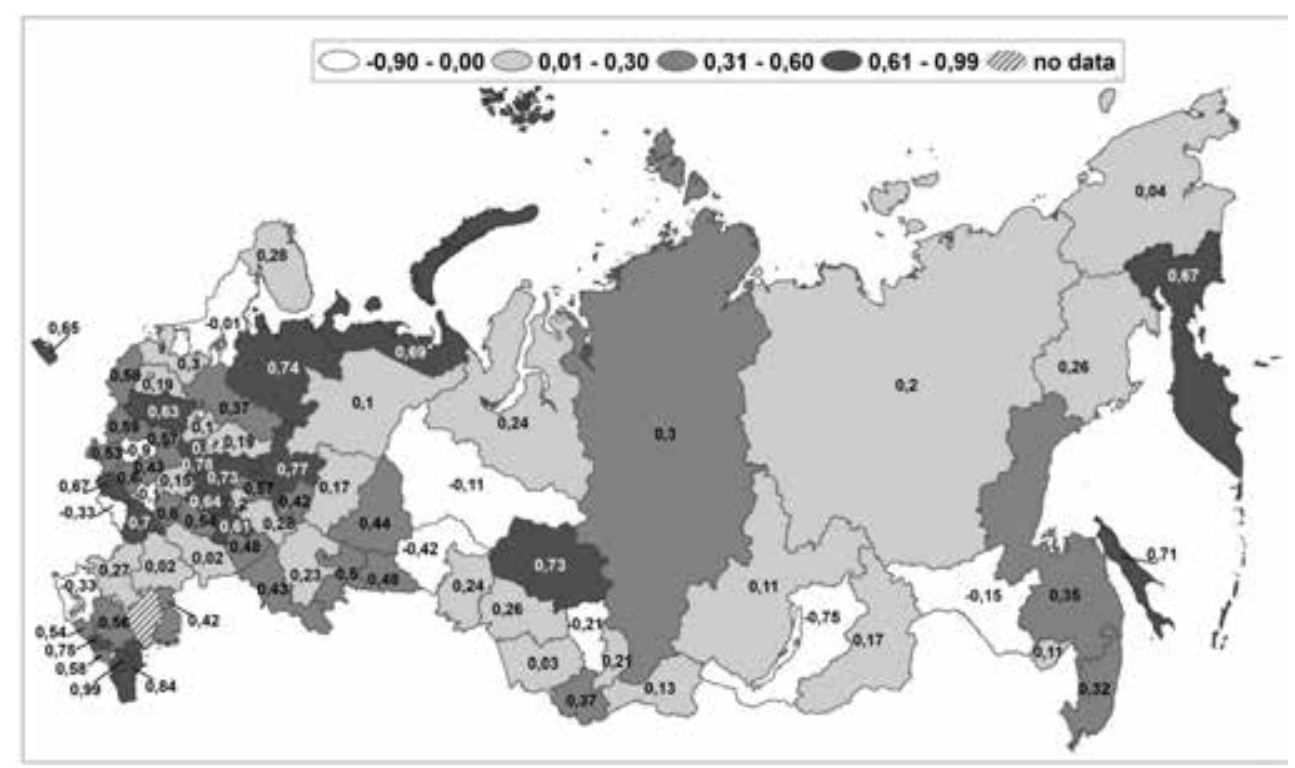

Fig. 3. The decoupling coefficient $\left(D_{t}\right)$ in Russia's regions: sulphur dioxide emissions from stationary sources, 2009 and 2017 


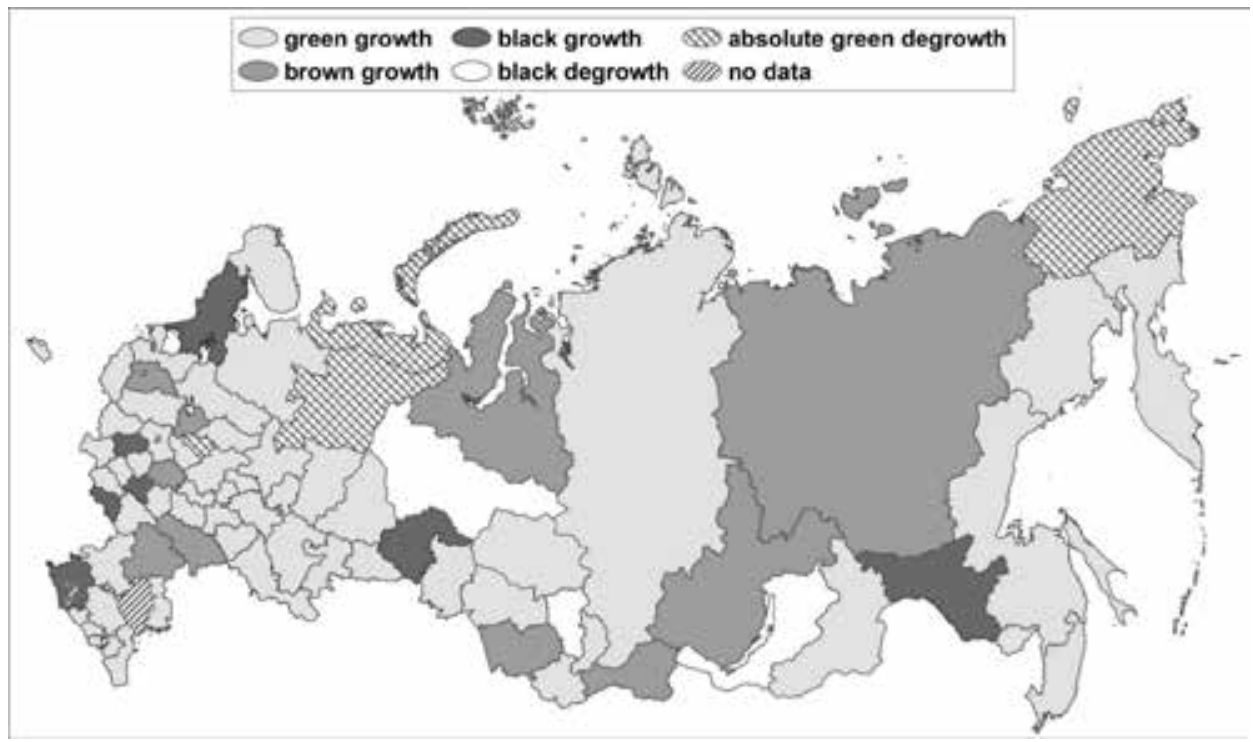

Fig. 4. Spatial distribution of the "color" of growth in the Russian regions during the 2009-2017 period by the ratio of sulphur dioxide emissions and GRP

Table 2. Nitrogen and carbon emissions for Krasnoyarsk and Trans-Baikal Territories (2009-2017)

\begin{tabular}{|l|c|c|c|}
\hline & Krasnoyarsk Territory & Trans-Baikal Territory & Russian Federation \\
\hline \multicolumn{3}{|c|}{ The decoupling coefficient $\left(D_{t}\right)$} \\
\hline Solid emissions & 0.30 & 0.21 & 0.38 \\
\hline Emissions of nitrogen oxides & 0.06 & 0.11 & 0.09 \\
\hline Carbon monoxide emissions & -0.55 & 0.10 & 0.25 \\
\hline \multicolumn{2}{|c|}{ "Color" of economic growth by the ratio of emissions from stationary sources and GRP } \\
\hline Solid emissions & Green growth & Green growth & Green growth \\
\hline Emissions of nitrogen oxides & Brown growth & Green growth & Brown growth \\
\hline Carbon monoxide emissions & Black growth & Green growth & Green growth \\
\hline
\end{tabular}

Source: calculated by the authors using the official data from the Federal State Statistics Service.

but also the prevention of environmental violations, as well as the establishment of rules for a rapid response to them.

Environmental institutions to a certain extent focus on the reduction of eco-intensity and the formation of the decoupling effect. Nevertheless even in this respect, their effectiveness is low; the calculations show a significant number of regions that are experiencing black growth and black degrowth. They are not immune to the formation of "brown" trends in the development of regional industry and the emergence of new industries. If the previous levels of pollution are maintained, even with a relatively "gentle" anthropogenic impact, the region will be doomed to "brown" growth with each new project. To move to "green" growth (or maintain the "green" development trend), a parallel environmental modernization of existing production facilities is necessary. It allows reducing the overall impact through the use of new technologies, improving energy efficiency, etc.

The "polluter pays" principle is implemented in the Russian institutional environment in the form of payments for emissions of 
pollutants. In order to reduce unit costs, manufacturers are upgrading to reduce eco-intensity. However, under conditions of resource abundance, this often leads to an increase in the economic attractiveness of the natural resource sectors, and ultimately to an increase in the negative impact on the environment. One of the most systematic studies of this issue presented in the paper (Tagaeva, 2011) shows that it is more profitable for most enterprises to transfer payments for pollution than to carry out environmental protection measures and environmental modernization of their production chains. In the system of economic regulation of environmental activities, payments for pollutant emissions do not properly take into account changes in price proportions under the conditions of inflation. The indexation rates for pollution charges for many years have not corresponded to the actual inflation rate, and were significantly lower. Calculations have shown that the existing payment standards are underestimated, especially in the Siberian Federal district (5-7 times), in the Ural Federal district (9-11 times, in the Far Eastern Federal district (10-12 times). Payments for negative environmental impacts are at best one-hundredth of a percent in the cost price and one-tenth of a percent of the enterprises' profit.

Having played a positive role in the first years after its formation, this institution has now largely lost the regulatory function for which it had been created. In (Glazyrina et al, 2017), it is shown that in the segment of subsurface use associated with the extraction of placer gold, this function is almost completely lost. As for the compensation function, that is, the role of this tool for collecting and accumulating funds for environmental purposes, it was significantly reduced after 2000 , when changes in budget legislation had led to the loss of the intended (environmental) purpose of these financial resources.

For most types of pollutants, the level of payments obviously does not correspond to the actual damage caused by emissions and discharges. Environmental payments reduce the profitability of commodity companies, and the examples of "environmental" lobbying support the hypothesis that if the state is dominated by institutions that promote rent-oriented behavior among the economic agents, then significant financial resources will be diverted and directed to unproductive activities. The struggle for rent in the raw materials industries is also manifested in the "suppression" of environmental laws, and becomes a more profitable activity than the development of environmentally friendly technologies.

\section{Conclusion}

The proposed tools allow analyzing environmental and economic trends for different types of negative anthropogenic impact. Based on the results of the calculations, it can be concluded that Russian environmental institutions are not sufficiently fine instruments of regulation, and do not fully take into account the regional characteristics and, in general, do not create sufficient incentives for greening the economy.

The weakness and inflexibility of the regional institutions is due to the current structure of distribution of rights and powers between the federal, regional and local levels of government. There is already a certain consensus in the scientific literature on the need to strengthen the regional level of regulation of environmental management processes. E. Ostrom notes that for successful regulation of the use of natural resources, it is extremely important to have operational and low-cost mechanisms for resolving emerging environmental and economic conflicts (Ostrom, 2009), which implies the presence of appropriate authorities at the regional and municipal levels. In Russia, the result of purposeful formation of the "vertical of power" was the practical absence of flexible and adaptive tools of state management that take into account the regional specifics and differences in the dynamics of socio-economic processes. The Russian "budget trichotomy" is becoming an increasingly noticeable barrier - the inability, except in special cases (under the threat of "misuse"), to combine financial resources at various levels to solve important and obvious problems, as well as to combine the resources of municipalities to solve common problems. Regional governments should 
have real capacity and resources to prevent and promptly resolve environmental problems, and to develop and implement long-term environmental programs and projects. It is very important that they can initiate economic in- centives for priority areas in the economy, create industries with deep processing of natural resources, technological and environmental modernization, set long-term goals and manage their achievement.

\section{References}

Alcott, B. (2005). Jevons' paradox. In Ecological Economics, 54(1), 9-21. DOI: 10.1016/j.ecolecon.2005.03.020

Baker, S. (2000). The European Union: integration, competitions, growth and sustainability. In Implementing Sustainable Development: Strategies and Initiatives in High Consumption Societies, 303-421.

Bobylev, S.N., Averchenkov, A.A., Soloveva, S.V., Kirushin, P.A. (2010). Energoeffektivnost' $i$ ustoichivoe razvitie [Energy Efficiency and Sustainable Development]. Moscow: Institut ustoichivogo razvitiia, $148 \mathrm{p}$.

De Haan, M. (2004). Accounting for goods and bads. Voorburg, Statistics Netherlands, 216 p.

Decoupling natural resource use and environmental impacts from economic growth. A Report of the Working Group on Decoupling to the International Resource Panel (2011). Available at: http://www.gci.org. uk/Documents/Decoupling Report English.pdf (accessed 14 June 2019).

Glazyrina, I.P., Mikheev, I.E., Eloyan, A.Yu. (2017). Accommodation of Ecological and Economic Interests in Placer Gold Mining. In Geography and Natural Resources, 38(3), 275-280. DOI: 10.1134/ S1875372817030088.

Glazyrina, I.P., Faleychik, L.M., et al. (2005). Ekologicheskie indikatory kachestva rosta regional'noi ekonomiki [Quality of growth indicators for regional economies]. Moscow, NIA-Priroda, $192 \mathrm{p}$.

Glazyrina, I.P., Fattahov, R.V., Deluga, A.V., Stroev, P.V., Grigorov, A.A. (2018) Baikal'skii region: "ekologicheskaia tsena" ekonomicheskogo rosta [The Baikal Region: "environmental cost" of economic growth]. In Region: Ekonomika i Sotsiologiia [Region: Economics and Sociology], 1(97), 231-249, DOI: 10.15372/REG20180111.

Glazyrina, I.P., Zabelina, I.A. (2016). The Silk Road Economic Belt and green growth in the east of Russia. In Journal of Resources and Ecology, 7(5), 342-351. DOI: 10.5814/j.issn.1674-764x.2016.05.004.

Glazyrina, I.P., Zabelina, I.A. (2018). Spatial heterogeneity of Russia in the light of the concept of a green economy: the social context. In Geography and Natural Resources, 39(2), 103-110. DOI: 10.21782/ GIPR0206-1619-2018-2(14-22).

Gulbrandsen, T.Kh., Padalko, L.P., Chervinskii, V.L. (2010). Energoeffektivnost' $i$ energeticheskii menedzhment [Efficiency and energy management]. Minsk, BGATU, $240 \mathrm{p}$.

Hovardas, T. (2016). Two paradoxes with one stone: a critical reading of ecological modernization. In Ecological Economics, 130, 1-7. DOI: 10.1016/j.ecolecon.2016.06.023

Jevons, W.S. (1905). The Coal Question: an Inquiry Concerning the Progress of the Nation, and the Probable Exhaustion of our Coal-mines. New York, Macmillan and Co, 467 p.

Kudryavtseva, O.V., Yakovleva, E.Y. (2019). Effekt dekaplinga i ekologicheskaia krivaia Kuznetsa $\mathrm{v}$ kontekste ekologo-ekonomicheskogo razvitiia regionov Rossii [Decoupling effect and environmental Kuznets curve in the context of ecological- economic development of Russian regions]. In Zelyonaia ekonomika i tseli ustoichivogo razvitiia dlia Rossii [Green economy and sustainable development goals for Russia]. Moscow, Faculty of Economics of Moscow state University, 152-157.

Mel'nikov, R.M. (2005). Analiz dinamiki mezhregional'nogo ekonomicheskogo neravenstva: zarubezhnye podkhody i rossiiskaya praktika [Analysis of the dynamics of regional economic differentiation: foreign approaches and domestic practice]. In Region: Ekonomika i Sotsiologiia [Region: Economics and Sociology], 4, 3-18.

Nagvi, A., Zwickl, K. (2017). Fifty shades of green: Revisiting decoupling by economic sector and air pollutants. In Ecological Economics, 133, 111-126. DOI: 10.1016/j.ecolecon.2016.09.017. 
O’Connor, J. (1994). The second contradiction of capitalism. In Capitalism Nature Socialism 5, 105114.

OECD annual report (2002). Available at: https://www.oecd.org/about/2080175.pdf (accessed 5 February 2020).

Ostrom, E. (2009). A general framework for analyzing sustainability of social-ecological systems. In Science, 325, 419-422.

Shang, Y., Si, Y., Zang, G. (2015). Black or Green? Economic growth patterns in China under low carbon economy targets. In Journal of Resources and Ecology, 6(5), 310-317.

Shkiperova, G.T. (2014). Analiz i modelirovanie vzaimosviazi mezhdu ekonomicheskim rostom i kachestvom okruzhaiushchei sredy (na primere Respubliki Kareliia) [Analysis and modeling of relationship between economic growth and environmental quality (the case of the Republic of Karelia)]. In Ekonomicheskii analiz: teoriia i praktika [Economic Analysis: Theory and Practice], 43 (394), 41-49.

Tagaeva, T.O. (2011). Improving environmental charges using results of the forecast of the environmental and economic development of the Russian Federation. In Studies on Russian Economic Development, 22(3), 331-338.

Tian, H. (2014). Advances in the study on endogenous sulfur dioxide in the cardiovascular system. In Chinese Medical Journal, 127(21), 3803-3807

Victor, P. (2015). The Kenneth E. Boulding Memorial Award 2014: Ecological economics: A personal journey. In Ecological Economics, 109, 93-100. DOI: 10.1016/j.ecolecon.2014.11.009.

Warner, R. (2010). Ecological modernisation theory: towards a critical ecopolitics of change? In Environmental Politics, 19(4), 538-556. DOI: 10.1080/09644016.2010.489710.

Wolfe, M. (2012). Beyond "green buildings": exploring the effects of Jevons' Paradox on the sustainability of archival practices. In Archival Science, 12(1), 35-50. DOI: 10.1007/s10502-011-9143-4.

Zabelina, I.A. (2019). Decoupling in environmental and economic development of regions-participants of cross-border cooperation. In Economic and Social Changes: Facts, Trends, Forecast, 12(1), 241-255. DOI: 10.15838/esc.2019.1.61.15.

Zabelina, I.A., Deluga, A.V. (2019a). Geoekologicheskie indikatory ustoichivogo razvitiia: prostranstvennyi analiz [Geoecological indicators of sustainable development: spatial analysis]. In Ustoichivoe razvitie gornykh territorii [Sustainable development of mountain territories], 11(1), 15-25. DOI: 10.21177/19984502-2019- 11-1-15-25.

Zabelina, I.A., Deluga, A.V. (2019b). Ekologo-ekonomicheskie tendentsii v baikal'skom regione i na dal'nem vostoke v usloviiakh institutsional'nykh izmenenii [Trends of Ecological and Economic Development of the Far East Regions and Sub-federal Units of the Baikal Region under Conditions of Institutional Change]. In EKO [ECO], 5(539), 66-88. DOI: 10.30680/ECO0131-7652-2019-5-66-88. 


\title{
Парадокс Джевонса:
}

\section{способствуют ли российские}

\section{природоохранные институты «зеленому» росту?}

\section{И.П. Глазырина, И.А. Забелина}

Лаборатория эколого-экономических исследований

Институт природных ресурсов, экологии и криологии СО РАН

Российская Федерация, Чита

Забайкальский государственный университет

Российская Федерация, Чита

\begin{abstract}
Аннотация. Целью данной работы является количественная оценка эффективности природоохранных институтов в России с позиций концепций «зеленой» экономики и «зеленого» роста. Для этих целей использовались показатели экологоэкономической динамики, которые можно рассматривать как характеристики качества экономического роста с экологической точки зрения: экоинтенсивность, которая представляет собой прямые количественные характеристики использования ресурсов или негативного воздействия на окружающую среду в расчете на единицу экономического результата, и коэффициенты декаплинга. Авторы придерживаются подхода к количественной оценке «зеленого» роста, предложенного П. Виктором в 2014 году. Предлагаемый инструментарий позволяет анализировать эколого-экономические тенденции для отдельных регионов, отраслей и видов экологической нагрузки. На основании результатов расчетов можно сделать вывод, что российские природоохранные институты не являются достаточно тонким инструментом регулирования, так как они не в полной мере учитывают региональные особенности и в целом не создают достаточных стимулов для экологизации экономики. Результаты работы могут быть использованы как в теоретических исследованиях эколого-экономической динамики отдельных стран и регионов, так и в практической разработке программ развития территорий.
\end{abstract}

Ключевые слова: экоинтенсивность, декаплинг, эколого-экономические тренды.

Работа выполнена в рамках Программы фундаментальных исследований СО РАН (XI.174.1).

Научная специальность: 08.00.05 - экономика и управление народным хозяйством. 